\title{
Diagnostic Importance of Saliva - An Overview
}

\author{
Angabeen Anjum ${ }^{1}$ \\ BDS \\ Mervyn Hosein ${ }^{2}$ \\ FDS RCS, FDS RCSE, FFD RCSI
}

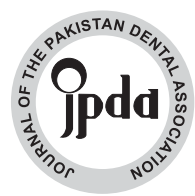

Saliva is an important and easily accessible bio-fluid having many diagnostic and prognostic applications. It serves as a window through which not only oral health but the overall systemic health status is determinable. Salivary biomarkers reveal a lot regarding disease risk, progress and resolution. Much research has been done in the past few decades on the diagnostic importance of biomarkers present in saliva. Minor bacterial infections to malignancies can manifest through saliva. Easy collection of saliva with a point-of-care facility facilitates both patients and clinicians in providing and collection of samples, respectively. This review highlights some of the essential diagnostic applications of saliva. Further researches can reveal more diagnostic and therapeutic modalities. Studies have reported the successful applications of saliva in cardiovascular disease detection, renal diseases monitoring, drug level monitoring, forensic examinations, premalignant and malignant disorders detection and oral pathologies. Psychological stress, physically active individuals and incremental effort test have also been monitored by the help of salivary diagnostics.

KEY WORDS: Salivary biomarkers, point-of-care facility, liquid biopsy specimen, therapeutic modalities.

HOW TO CITE: Anjum A, Hosein M. Diagnostic importance of saliva - an overview . J Pak Dent Assoc 2019;28(3):129-135. DOI: https://doi.org/10.25301/JPDA.283.129

Received: 29 December 2018, Accepted: 18 May 2019

\section{INTRODUCTION}

$\mathrm{D}$ iagnostic applications of saliva were established at the beginning of this century. ${ }^{1}$ Salivary testing for assessment of health or diseased states is gaining increasing importance. ${ }^{2}$ Saliva is one of the biologic fluids of the human body, heterogeneous in nature, slightly acidic $(\mathrm{pH}=6.0-7.0)$ and clear. ${ }^{3}$ Major and minor salivary glands secretions along with gingival crevicular fluid jointly constitute the saliva. ${ }^{4}$ Functions of saliva include lubrication, assistance in speech, digestion and general maintenance of oral health etc. ${ }^{5}$ Moreover saliva's buffering capacity protects teeth enamel from acidic attack and helps in remineralization. ${ }^{6}$ Mucus secretions of saliva also act as a shield protecting the oral mucosa from irritants and infections. ${ }^{7}$ These functions are performed by its various chemical components including water, inorganic compounds (ions), organic compounds (non-proteins and lipids), proteins/polypeptides and hormones. ${ }^{6}$ Collection of saliva is straightforward, easy ,requires little equipment and is repeatable without discomfort, making it an excellent diagnostic tool. ${ }^{1}$ For diagnosing and monitoring caries risk, microbial sepsis, inflammation and genetic pathologies including oral tumors and cysts, a variety of saliva based diagnostic approaches have been developed during the last decade. ${ }^{8}$ Salivary

1. Lecturer, Department of Pharmacology, Sir Syed College of Medical Sciences for Girls,Karachi.

2. Principal, Ziauddin College of Dentistry, Ziauddin University.

Corresponding author: "Dr. Angabeen Anjum" < angabeen.anjum@gmail.com > diagnostics which is gaining increasing importance is the subset of molecular diagnostics which has brought revolution in the field of medicine and dentistry. Successful role of molecular diagnostics has been documented in different areas including biomarkers discovery for detecting different systemic and oral diseases, drug development and personalized medicine (pharmacogenomics). The successful applications of salivary diagnostics is made possible by novel molecular approaches including transcriptomics, proteomics and genomics. ${ }^{9}$

Figure 1: Properties making saliva the best diagnostic tool

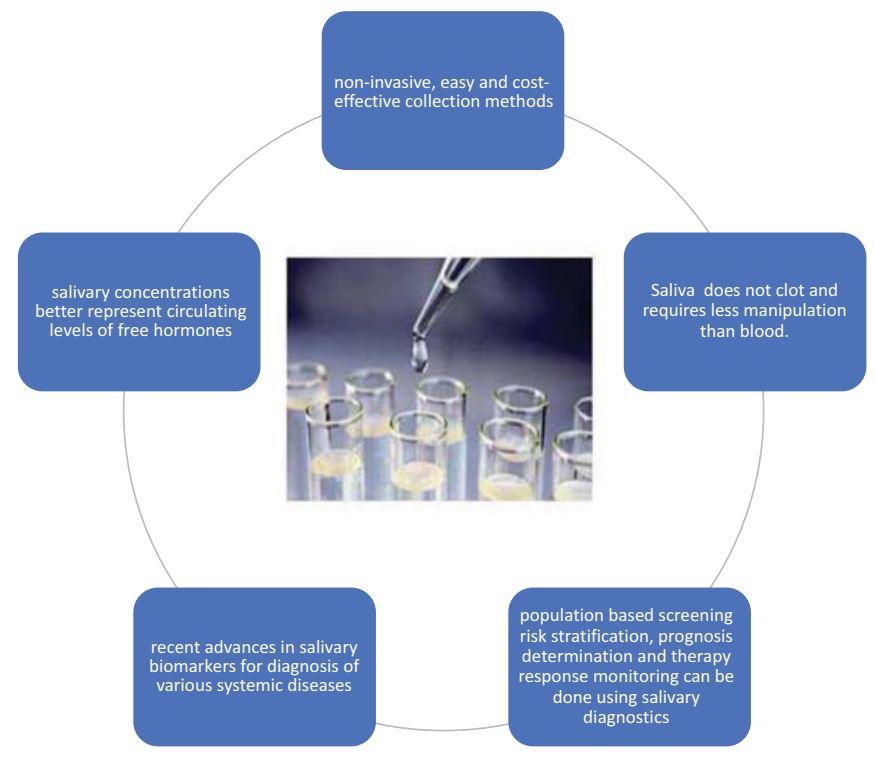




\section{Diagnostic significance of saliva - A brief discussion Saliva as the best point of care diagnostic tool}

Point-of-care medicine means to provide care, treatment and testing facilities to patients on presentation site..$^{10}$ This improves patients outcomes in critical care settings, helps medical teams to get timely information and contributes to rational and time-critical decision making. ${ }^{11}$ Over the past few decades, saliva testing has increased as the liquid biopsy specimen for detection of different diseases. ${ }^{12}$

Oral diseases detectable through saliva include dental caries, gingivitis, periodontitis (chronic/aggressive), Behcet's disease, squamous cell carcinoma, salivary gland diseases, leukoplakia and chronic graft-versus-host disease (cGVHD) etc.

Breast cancer, diabetes and AIDS(acquired immunodeficiency syndrome) are some of the saliva detectable systemic diseases. ${ }^{12}$

Figure 2: Diagnostic applications of saliva in different systemic diseases.

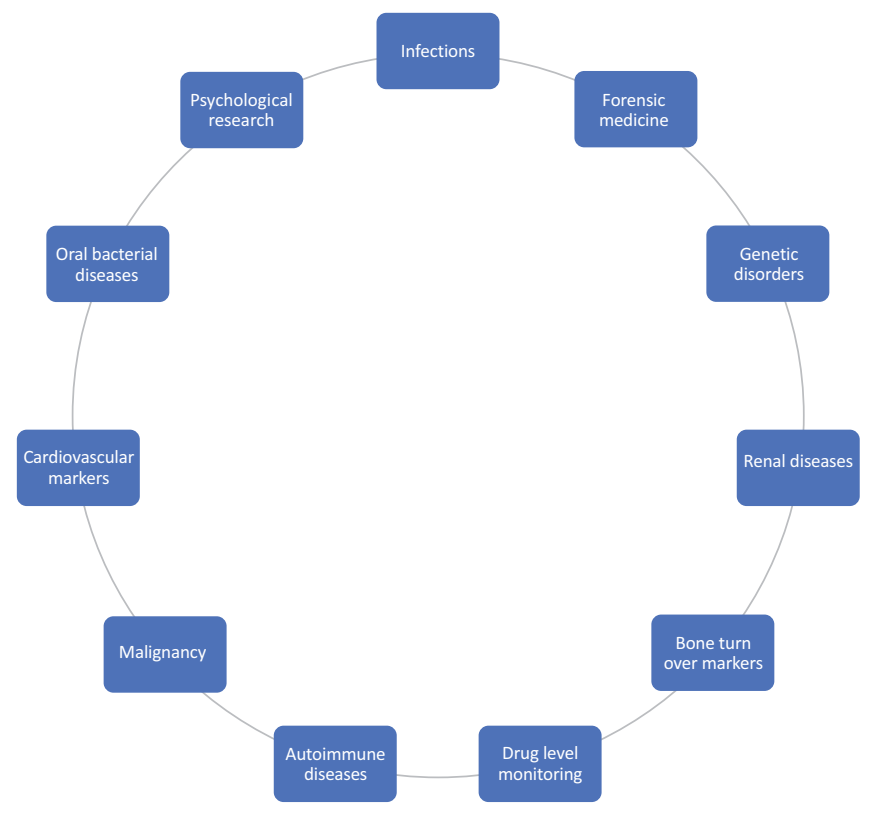

\section{Salivary Biomarkers}

Any cellular, biochemical, molecular, or genetic alterations which help to recognize and monitor disease susceptibility, progression, resolution, health status and treatment outcome in individuals is termed a biomarker. ${ }^{5}$ Biomarkers are found in blood, saliva and other body fluids. ${ }^{12}$ Analytes found in saliva include steroid hormones, enzymes, mucins, cystatins, histatins, antibodies, cytokines etc. ${ }^{13}$ Salivary biomarkers and aanalytes also have the potential to predict health status of people including hormonal variations, substances abuse, status of infectious disease etc. ${ }^{13}$
Salivary biomarkers in Cardiovascular disease detection

Salivary biomarkers serve as very important diagnostic tools for cardiovascular disease. ${ }^{12}$ These include Cardiac troponin I, Myoglobin, Creatine phosphokinase MB, Myeloperoxidase, C-Reactive Protein, brain natriuretic peptide, Matrix metalloproteinase-8, MMP-9. ${ }^{12}$ In emergencies, rapid diagnosis of acute myocardial infarction can be made through salivary biomarkers such as Creatine kinase muscle/brain (CK-MB), Troponin T(TnT), Troponin $\mathrm{I}(\mathrm{TnI}), \mathrm{C}$-reactive protein $(\mathrm{CRP})]$ and active matrix metalloproteinase (MMP)-8. ${ }^{14}$ Miller et al in their study evaluated salivary $\mathrm{C}$ reactive protein, soluble intercellular adhesion molecule-1 (sICAM-1) as well as Adiponectin as classical indicators of Acute Myocardial Infarction (MI). ${ }^{14}$ Under certain conditions (Childhood maltreatment and intimate partner violence (IPV), the conditions perceived as chronic stressors and provoke general inflammation reported in studies), low grade inflammation and risk status for cardiovascular disease can also be reflected in levels of salivary $\mathrm{C}$ reactive protein.$^{15}$

\section{Salivary biomarkers in premalignant and malignant disorders}

Two types of biomarkers are used in cancer detection ; prognostic and diagnostic. ${ }^{16}$

A diagnostic biomarker helps in detection or confirmation of disease or condition of interest, while the disease progression, its likely course and recurrence is identified by prognostic biomarker. ${ }^{17}$

Salivary biomarkers have been investigated in different types of cancer. ${ }^{18}$ Different studies suggest that the level of IL- $\beta$ is fundamentally higher in cancer patients and is more easily detected in saliva than in blood. ${ }^{18}$ Several salivary protein markers, for example, matrix metalloproteinase (MMP 2, 9), interleukins $(8,6,1 \mathrm{~b})$, transferrin, tumor necrosis factor (TNF- $\alpha$ ), transforming growth factor (TGF-1) and catalase have been identified in oral squamous cell carcinoma. ${ }^{19}$ Many protein biomarkers including Matrix metalloproteinases ,cytokines, vascular endothelial growth factor A (VEGF-A), Tumor necrosis factor alpha (TNF- $\alpha$ ) and mRNA salivary biomarkers such as Ornithine decarboxylase antizyme 1 (OAZ1), Dual specificity phosphatase 1 (DUSP1), S100 calcium binding protein $\mathrm{P}$ (S100P),Spermidine/spermine N1-acetyltransferase 1 (SAT1) have been identified to detect OSCC with high sensitivity and specificity(20). In a study by Stott-Miller et al, concentrations of MMP1 and MMP3 were tested in saliva samples from 100 subjects (60 primary OSCC cases, 15 dysplasia cases, and 25 controls). The protein concentrations were higher in the saliva from OSCC patients compared to the saliva from cancer-free controls. As matrix 
metalloproteinases (MMP) use to cause degradation of the basement membranes and extracellular matrix so this study finding suggests its key role in cancer development. Studies have reported MMPs , the potential cancer biomarkers and they have found to cause metastasis and tumor invasion..$^{20}$ Cytokines especially Interleukin-6 (IL-6),Interleukin-8 (IL-8) and Tumor necrosis factor (TNF- $\alpha$ ) are potential biomarkers of cancer because they are greatly expressed in the saliva of cancer patients and are involved in the pathogenesis of cancer(21).Salivary IL-6 also showed greater expression in oral premalignant disorders. In a study by Thalayan et al, significant differences in IL- 6 concentration were noted between OSCC and premalignant disorder patients in both serum and saliva, with salivary levels being 2 to 3 fold higher than serum values across the groups. ${ }^{22}$ Significant rise in salivary TNF- $\alpha$ and INF- $\gamma$ has been demonstrated in oral lichen planus patients compared with healthy individuals. $^{23}$

\section{Salivary biomarkers in gastrointestinal disorders}

Saliva can aid testing in a variety of GI disorders. Typhoid is a major enteric fever.In a study by Herath et al., evaluation of salivary IgA antibodies against Lipopolysaccharides (LPS) of Salmonella was done with assay sensitivity of $83 \%$ and specificity of $97 \%$, respectively. ${ }^{24}$

Immune responses during typhoid infection can also be recognized through salivary $\operatorname{IgA}$ antibody against recombinant haemolysin $\mathrm{E}$ (rHlyE) protein from $\mathrm{S}$. typhi and this can serve as a biomarker. ${ }^{25}$ Detection of typhoid fever using this rHlyE) antigen with a sensitivity of $70 \%$, and a specificity of $100 \%$ is reported in a study. ${ }^{25}$ Salivary pepsin detection can help in the diagnosis of gastroesophageal reflux disease (GERD) but further work is needed to make it a more accurate tool. ${ }^{26}$

Inflammatory reactions may manifest in the oral cavity of patients suffering from Ulcerative colitis (UC), Crohn's disease(CD) and Irritable bowel disease(IBS) and detectable higher levels of salivary cytokines and IgA in these patients as compared to healthy individuals. ${ }^{27}$ In Crohn`s disease patients ,higher levels of TNF- $\alpha$, IL- 6 and IL- $1 \beta$ have been observed and on the other hand raised salivary IL-8 level has been reported in IBS patients. ${ }^{27}$ Decreased levels of salivary lysozyme have also been reported in CD and UC patients compared with healthy individuals. ${ }^{27}$

\section{Salivary biomarkers in sjogren syndrome}

Primary Sjören's syndrome (pSS) is an autoimmune disease in which the patients suffer from dry eyes and dry mouth, caused by nonfunctioning of salivary and lacrimal glands. ${ }^{28}$ Gross cystic disease fluid protein-15 (GCDFP-15)/prolactin-inducible protein (PIP) as a classical biomarker for primary Sjögren's syndrome is established. ${ }^{28}$ The process of saliva production requires trans-epithelial water transfer from the glandular interstitium to the acinar lumen. ${ }^{29}$

A salivary gland water channel Aquaporin 5 (AQP5) is down-regulated in primary Sjören's syndrome. This water channel helps in saliva formation, with this aquaporin 5, (GCDFP-15) binds and this is supposed to be the cause of reduced salivation. ${ }^{28}$ Baldini et al.in their study confirmed significant reduction of GCDFP-15/PIP in the saliva of pSS as compared to healthy individuals. ${ }^{30}$

\section{Salivary biomarkers in infectious diseases ORAL BACTERIAL DISEASES}

The two most common bacterial diseases of the oral cavity are caries and periodontitis. ${ }^{9}$ Periodontal disease parameters and the levels of matrix metalloproteinase (MMP)8 , salivary IL-1 $\beta$, and osteoprotegerin (OPG) in saliva have been studied by Teles et al. Greater concentrations of MMP8 and salivary IL- $1 \beta$ were reported in periodontitis patients than in healthy controls suggesting that the oral epithelial cells increase the secretion of cytokines proportional to the progress of periodontal chronic inflammation and infection with periodontal pathogens. ${ }^{31}$ Raised levels of inflammatory mediators of $\beta$-glucuronidase, TNF- $\alpha$, IL- 6 and IL- $1 \beta$ in saliva and TNF- $\alpha, \mathrm{IL}-1 \beta$ and $\beta$-glucuronidase in serum have been found in females suffering from periodontitis patients relative to healthy controls. ${ }^{32}$ Salivary diagnostics is equally important for caries assessment. ${ }^{9}$ Streptococcus mutans (S. mutans), Streptococcus sobrinus (S. sobrinus), and lactobacilli are the common caries causing pathogens. Caries susceptibility have been found to be raised in children having reduced salivary levels of alpha-defensins Human Neutrophil Peptides (HNP1-3) while the agglutination of streptococci is promoted by salivary mucins (i.e. MUC7). Salivary flow rate, salivary $\mathrm{pH}$ and buffer capacity can also help in assessing caries risk. ${ }^{7}$

\section{ORAL VIRAL DISEASES}

Antibody response to infection is the basis on which the majority of virology diagnoses are made. ${ }^{3}$ Diagnosis of congenital infections, acute viral infections and reactivation of latent infection can be made by detecting salivary antibodies against the viruses or their components. ${ }^{3}$ Human cytomegalovirus (HCMV) is the commonest pathogen causing congenital infection globally. ${ }^{33}$ The diagnosis of congenital infection is based either on viral isolation (in cell culture) or demonstration of HCMV DNA from the urine or saliva ${ }^{33}$ .Immunoglobulins are important defensive shields, secretory IgA derived from plasma cells in the salivary glands, is the predominant one. ${ }^{34}$ 
In Dengue endemic regions, Dengue virus specific IgA in saliva was detected. ${ }^{35}$ Moreover antibodies directed against specific antigens of Plasmodium falciparum antigens, dengue virus, and Ebola virus have also been detected in saliva ${ }^{36}$

Human herpes virus, HIV infection, Epstein-Barr virus, Cytomegalovirus and hepatitis $\mathrm{C}$ virus can easily be detected using saliva as the bio specimen. It has good sensitivity and specificity and is the best alternative to serum. ${ }^{3}$ One of the common causes of diarrhea in children is Rotavirus $(\mathrm{RV})$ infection that can lead to serious dehydration and the ultimate need of hospitalization. Rota virus affects the terminally differentiated enterocytes in the small intestine and cause villus atrophy ,epithelial cells necrosis and mucosal damage.Gómez-Rial et al in their study observed increased levels of salivary epidermal growth factor(EGF)in infants during the acute phase of rotavirus infection and levels correlated with the period of hospitalization. ${ }^{37}$ Study suggested the elevated levels of EGF as a result of host recovery response to the mucosal damaged caused by virus. Raised levels of EGF has reported in studies in diseases associated with mucosal disruptions and alterations, also expressed in the submandibular salivary glands, in order to restore the integrity of mucosa after infection. ${ }^{37}$

\section{ORAL FUNGAL DISEASES}

Saliva is a diagnostic tool in oral fungal infections. ${ }^{3}$ Clinical examination along with analysis of saliva, swabs etc. are the diagnostic tools for oral mycoses including oropharyngeal candidiasis (OPC). Saliva and scrapings analysis involves in vitro culturing to isolate and identify the etiological agent, direct microscopic and histopathological examination for confirmation and to assess the severity of tissue damage. ${ }^{9}$

\section{APPLICATIONS OF SALIVARY BIOMARKERS IN OTHER DISEASES}

Three salivary biomarkers, procalcitonin (PCT), C-reactive protein (CRP), and neutrophil elastase (NE) are found to be raised during Chronic obstructive pulmonary disease (COPD) exacerbations.

In such exacerbations, CRP and PCT correlated well with patient-derived clinical metrics .So COPD can be better evaluated and managed by using these parameters ${ }^{38}$ Numerous salivary markers are related with end stage renal disease including uric acid, cortisol, nitrite, lactoferrin ,sodium, chloride, $\mathrm{pH}$ etc. ${ }^{9}$ A study reported the use of colormetric test strips for screening salivary nitrate and uric acid before and after hemodialysis thus making patients aware of the right time for dialysis. ${ }^{9}$ Hyperphosphatemia, the major cause of cardiovascular calcification in chronic renal failure patients, is detectable in salivary phosphate whose levels correlated positively with serum creatinine and the glomerular filtration rate and thus may serve as a better marker than serum phosphate in the management of chronic renal failure patients. ${ }^{9}$

Cortisol, salivary amylase, lysozyme, substance $\mathrm{P}$, and secretory IgA are some of the stress and pain- related markers found in saliva. ${ }^{9}$ Violent behavior and strenuous physical activities also correlate with salivary testosterone levels. ${ }^{9}$ Cognitive behavior can be assessed by evaluating salivary tryptophan and serotonin levels. ${ }^{9}$ Thus salivary samples can be pivotal in psychological research and management. ${ }^{9}$ Forensic diagnostics have largely been through saliva samples along with other body fluids. ${ }^{39}$ DNA and blood-group antigens including $\mathrm{A}, \mathrm{B}, \mathrm{H}$, and Lewis antigens are also detected in saliva and used for criminal identification and paternity law suit cases. ${ }^{9}$

Saliva can also facilitate neonatal diagnosis and prognosis utilizing different biomarkers found during neonatal infections. These include cytokines [TNF- $\alpha$, interleukin (IL)-1 alpha/beta, IL-2, IL-6, IL-8], complement fragments (C3, C4), MMPs 1-3, 9, multiple antimicrobial proteins/peptides (lactoferrin, histatin, cathelicidin ,alpha and beta-defensins, S100 proteins), acute phase reactants (C-reactive protein, haptoglobin, transferrin, fibronectin) and immunoglobulins (IgG, $\operatorname{IgE}$, and $\operatorname{IgM}){ }^{40}$

Incorporating newer technologies in salivary diagnostics can bring much improvement in infant and child health and also provide better options for disease investigations. ${ }^{41}$ Neonatal sepsis, one of the major causes of infant death is also associated with brain injury in many cases. ${ }^{42}$ Detection of $\mathrm{C}$ reactive protein in saliva can inform care givers about the risk status and progress of sepsis and other infections in infants and can reduce the need for repeated phlebotomies. ${ }^{42}$

Saliva is a very important medium for detecting drug abuse with noninvasive and point of care collection facilities. ${ }^{43}$ Various researches have been done regarding qualitative and quantitative drugs analysis and the pharmacovigilance potential of saliva. ${ }^{44} \mathrm{~A}$ significant positive correlation has been observed between serum and salivary drug levels in many studies.

Therapeutic drug monitoring (TDM), a procedure done in order to improve and assess patient's management who is receiving the drug therapy is also flourishing as a result of salivary diagnostics. In therapeutic drug monitoring, drug concentration in patient's biological fluid is measured and correlates with the clinical condition so that the finding can be used in adjusting the dosage or dosage intervals. Saliva is preferable over serum or blood for TDM because it can reflect the free non-protein bound pharmacologically active component in serum. Saliva has also facilitated drug testing in different conditions including drug identification of possible 
drug-affected drivers, workplace testing particularly following a safety incident, to check for possible drug use, testing of persons in prisons and other correctional institutions, the monitoring of drug use by drug courts, or testing of detainees suspected of a crime who may be under the influence of a drug and for sport anti-doping test. Antiepilteptics, immunosuppresants, theophylline, cocaine, amphetamine, barbiturates, benzodiazipines and opioids are some of the drugs whose surveillance have been done using saliva. ${ }^{44}$

\begin{tabular}{|c|c|c|c|}
\hline S.NO. & Diseases & Biomarkers & $\begin{array}{l}\text { Source of } \\
\text { biomarkers }\end{array}$ \\
\hline 1 & $\begin{array}{l}\text { Dental caries and } \\
\text { periodontal diseases }\end{array}$ & $\begin{array}{l}\text { Streptococcus mutans and lactobacilli count, } \\
\text { aspartate aminotransferase,alkaline phosphatase, } \\
\text { uric acid ,albumin etc. }\end{array}$ & Saliva \\
\hline 2 & $\begin{array}{l}\text { Autoimmune diseases } \\
\text { (Sjogren's } \\
\text { syndrome,multiple } \\
\text { sclerosis, sarcoidosis) }\end{array}$ & $\begin{array}{l}\text { Lactoferrin,beta } 2 \text { microglobulin,lysozyme C, } \\
\text { Cystatin C, salivary amylase, carbonic } \\
\text { anhydrase ,IgA production }\end{array}$ & Saliva \\
\hline 3 & $\begin{array}{l}\text { Cardiovascular } \\
\text { markers }\end{array}$ & $\begin{array}{l}\text { Cardiac troponins, C reactive protein, } \\
\text { myoglobin, myeloperoxidase, } \\
\text { ICAM-1,CD } 40 \text { and salivary lysozyme }\end{array}$ & $\begin{array}{l}\text { Serum and } \\
\text { saliva }\end{array}$ \\
\hline 4 & Drug level monitoring & $\begin{array}{l}\text { Nicotine, Cannabinoids, cocaine, phencyclidine, } \\
\text { Opioids, barbiturates, amphetamines, ethanol, } \\
\text { etc. }\end{array}$ & $\begin{array}{l}\text { Serum and } \\
\text { saliva }\end{array}$ \\
\hline 5. & Forensic evidence & Blood group antigens and DNA testing & Saliva \\
\hline 6. & Malignancy & $\begin{array}{l}\text { Inc. RNA,miRNA,CCNI,EGFR,FGF19,FRS2 } \\
\text {,IL1B,p53,CA15-3,cortisol,lactate } \\
\text { dehydrogenase, silver nitrate etc. }\end{array}$ & $\begin{array}{l}\text { Serum and } \\
\text { saliva }\end{array}$ \\
\hline 7. & $\begin{array}{l}\text { Occupational and } \\
\text { environmental } \\
\text { medicine }\end{array}$ & $\begin{array}{l}\text { Salivary cortisol,IgA, } \\
\text { lysozyme,chromogranin,alpha-amylase,lead and } \\
\text { cadmium. }\end{array}$ & $\begin{array}{l}\text { Serum and } \\
\text { saliva }\end{array}$ \\
\hline 8. & Renal diseases & $\begin{array}{l}\text { Cortisol, nitrite, uric acid, sodium chloride, } \mathrm{pH} \text {, } \\
\text { alpha-amylase,lactoferrin,salivary phosphate, } \\
\text { serum creatinine and glomerular filtration rate. }\end{array}$ & $\begin{array}{l}\text { Serum and } \\
\text { saliva }\end{array}$ \\
\hline 9. & $\begin{array}{l}\text { Psychological } \\
\text { research }\end{array}$ & $\begin{array}{l}\text { Salivary amylase, cortisol, substance } P \text {, } \\
\text { lysozyme, secretory } \operatorname{IgG} \text { and testosterone. }\end{array}$ & Saliva \\
\hline 10. & $\begin{array}{l}\text { Bone tum over } \\
\text { markers }\end{array}$ & $\begin{array}{l}\text { Interleukin } 1 \text { beta, salivary osteonectin , alkaline } \\
\text { phosphatase activity etc. }\end{array}$ & $\begin{array}{l}\text { Senum and } \\
\text { saliva }\end{array}$ \\
\hline
\end{tabular}

Table 1: Salivary biomarkers in different systemic diseases

\section{CONCLUSION}

Saliva as a diagnostic fluid fulfill many of the investigative needs for detection of different diseases and some times more beneficial than serum and blood. Screening of large population can be done with the help of salivary diagnostics as it has easy, cost effective and noninvasive approach. The examination of salivary fluid can play a very important role in clinical diagnosis of systemic diseases. Biomarkers found in saliva can assist in disease detection, management and progress. Progress through further studies can facilitate both patients and clinicians and help in improvement of health sciences.

\section{CONFLICT OF INTEREST}

None declared

\section{REFERENCES}

1. Aro K, Wei F, Wong DT, Tu M. Saliva Liquid Biopsy for Point-ofCare Applications. Frontiers in public health. 2017;5-13.

https://doi.org/10.3389/fpubh.2017.00077

2. Lee J, Garon E, Wong D. Salivary diagnostics. Ortho craniofac Res. 2009;12:206-11.

https://doi.org/10.1111/j.1601-6343.2009.01454.x

3. Greabu M, Battino M, Mohora M, Totan A, Didilescu A, Spinu T, et al. Saliva--a diagnostic window to the body, both in health and in disease. J Med life. 2009;2:124-32.

4. Spielmann N, Wong DT. Saliva: diagnostics and therapeutic perspectives. Oral dis. 2011;17:345-54.

https://doi.org/10.1111/j.1601-0825.2010.01773.x

5. Rahim MAA, Rahim ZHA, Ahmad WAW, Hashim OH. Can saliva proteins be used to predict the onset of acute myocardial infarction among high-risk patients? Int J med sci. 2015;12:329-35. https://doi.org/10.7150/ijms.11280

6. Cheng Y-SL, Rees T, Wright J. A review of research on salivary biomarkers for oral cancer detection. Clin translati medi. 2014;3: 3-12.

https://doi.org/10.1186/2001-1326-3-3

7. Kaczor-Urbanowicz KE, Martin Carreras-Presas C, Aro K, Tu M, Garcia-Godoy F, Wong DT. Saliva diagnostics-Current views and directions. Experiment Biol Medi. 2017;242:459-72. https://doi.org/10.1177/1535370216681550

8. Gutiérrez-Corrales A, Campano-Cuevas E, Castillo-Dalí G, TorresLagares D, Gutiérrez-Pérez J-L. Ability of salivary biomarkers in the prognostic of systemic and buccal inflammation. J clini experiment dent. 2017;9:e716.

https://doi.org/10.4317/jced.53776

9. Malamud D. Saliva as a diagnostic fluid. Dental Clin North Am. 2011;55:159-78.

https://doi.org/10.1016/j.cden.2010.08.004

10. Carleton PF, Schachter S, Parrish JA, Collins JM, Crocker JB, Dixon RF, et al. National Institute of Biomedical Imaging and Bioengineering point-of-care technology research network: Advancing precision medicine. IEEE J translat eng health med. 2016;4:1-14. https://doi.org/10.1109/JTEHM.2016.2598837

11. Hart R, Mauk M, Liu C, Qiu X, Thompson J, Chen D, et al. Pointof-care oral-based diagnostics. Oral dis. 2011;17:745-52. https://doi.org/10.1111/j.1601-0825.2011.01808.x

12. Rehman AS, Khurshid Z, Hussain Niazi F, Naseem M, Al Waddani $\mathrm{H}$, Sahibzada HA, et al. Role of Salivary Biomarkers in Detection of Cardiovascular Diseases (CVD). Proteomes. 2017;5:21- 26. https://doi.org/10.3390/proteomes5030021

13. Granger DA, Johnson SB, Szanton SL, Out D, Schumann LL. 
Incorporating salivary biomarkers into nursing research: an overview and review of best practices. Biol Res Nurs. 2012;14:347-56. https://doi.org/10.1177/1099800412443892

14. Miller C, Foley III J, Floriano P, Christodoulides N, Ebersole J, Campbell $\mathrm{C}$, et al. Utility of salivary biomarkers for demonstrating acute myocardial infarction. J Dent Res. 2014;93(7_suppl):72S-9S. https://doi.org/10.1177/0022034514537522

15. Out D, Hall RJ, Granger DA, Page GG, Woods SJ. Assessing salivary C-reactive protein: longitudinal associations with systemic inflammation and cardiovascular disease risk in women exposed to intimate partner violence. Brain, behavior, immunity. 2012;26: 543-51.

https://doi.org/10.1016/j.bbi.2012.01.019

16. Kaczor-Urbanowicz KE, Martín Carreras-Presas C, Kaczor T, Tu M, Wei F, Garcia-Godoy F, et al. Emerging technologies for salivaomics in cancer detection. J Cellular Molecular Med. 2017;21:640-7. https://doi.org/10.1111/jcmm.13007

17. Califf RM. Biomarker definitions and their applications. Experimental Biol Med. 2018;243:213-21.

https://doi.org/10.1177/1535370217750088

18. Idris A, Ghazali NB, Koh D. Interleukin $1 \beta$-A Potential Salivary Biomarker for Cancer Progression? Biomarkers Cancer. 2015;7:25-9. https://doi.org/10.4137/BIC.S25375

19. Radhika T, Jeddy N, Nithya S, Muthumeenakshi R. Salivary biomarkers in oral squamous cell carcinoma-An insight. J Oral Biol Craniofac Res. 2016;6:S51-S4.

https://doi.org/10.1016/j.jobcr.2016.07.003

20. Yakob M, Fuentes L, Wang MB, Abemayor E, Wong DT. Salivary biomarkers for detection of oral squamous cell carcinoma: current state and recent advances. Current oral health reports. 2014;1:133-41. https://doi.org/10.1007/s40496-014-0014-y

21. Sahibzada HA, Khurshid Z, Khan RS, Naseem M, Siddique KM, Mali M, et al. Salivary IL-8, IL-6 and TNF- $\alpha$ as Potential Diagnostic Biomarkers for Oral Cancer. Diagnostics. 2017;7:21-30. https://doi.org/10.3390/diagnostics7020021

22. Dineshkumar T, Ashwini BK, Rameshkumar A, Rajashree P, Ramya R, Rajkumar K. Salivary and serum interleukin-6 levels in oral premalignant disorders and squamous cell carcinoma: diagnostic value and clinicopathologic correlations. Asian Pacific J cancer prevent: APJCP. 2016;17:4899-906.

23. Ghallab NA, El-Wakeel N, Shaker OG. Levels of salivary IFNgamma, TNF-alfa, and TNF receptor-2 as prognostic markers in (erosive) oral lichen planus. Mediators Inflammation. 2010; Vol no 2010 Article ID 847632

https://doi.org/10.1155/2010/847632

24. Redhuan NEM, Chin KL, Adnan AS, Ismail A, Balaram P, Phua KK. Salivary Anti-50 kDa Antibodies as a Useful Biomarker for Diagnosis of Typhoid Fever. J Clini Diag Res: JCDR. 2017;11(6):DC10. https://doi.org/10.7860/JCDR/2017/21928.10055
25. Chin KL, Redhuan NEM, Balaram P, Phua KK, Ong EBB. Detection of Salivary IgA Antibodies Against the HlyE Antigen as a Diagnosis of Typhoid Fever. J clini diag res JCDR. 2016;10:DM01. https://doi.org/10.7860/JCDR/2016/17801.7909

26. Du X, Wang F, Hu Z, Wu J, Wang Z, Yan C, et al. The diagnostic value of pepsin detection in saliva for gastro-esophageal reflux disease: a preliminary study from China. BMC gastroenterolog. 2017;17:107115.

https://doi.org/10.1186/s12876-017-0667-9

27. Said HS, Suda W, Nakagome S, Chinen H, Oshima K, Kim S, et al. Dysbiosis of salivary microbiota in inflammatory bowel disease and its association with oral immunological biomarkers. DNA res. 2013;21:15-25.

https://doi.org/10.1093/dnares/dst037

28. Gallo A, Martini D, Sernissi F, Giacomelli C, Pepe P, Rossi C, et al. Gross cystic disease fluid protein-15 (GCDFP-15)/prolactininducible protein (PIP) as functional salivary biomarker for primary Sjögren's syndrome. J geneti syndro \& gene therap. 2013;4:1-19.

29. Matsuzaki T, Susa T, Shimizu K, Sawai N, Suzuki T, Aoki T, et al. Function of the membrane water channel aquaporin- 5 in the salivary gland. Acta histochemica et cytochemica. 2012;45:251-59. https://doi.org/10.1267/ahc.12018

30. Baldini C, Martini D, Sernissi F, Gallo A, Rossi C, Mosca M, et al. THU0304 Gross Cystic Disease Fluid Protein-15 (GCDFP15)/Prolactin-Inducible Protein (PIP): A Functional Salivary Biomarker for Primary SjöGren's Syndrome? Annals Rheumatic Dis. 2013;72(Suppl 3):A268-A9.

https://doi.org/10.1136/annrheumdis-2013-eular.832

31. Teles R, Likhari V, Socransky S, Haffajee A. Salivary cytokine levels in subjects with chronic periodontitis and in periodontally healthy individuals: a cross? sectional study. Journal of periodont res. 2009;44:411-17.

https://doi.org/10.1111/j.1600-0765.2008.01119.x

32. Jiang H, Zhang Y, Xiong X, Harville EW, Karmin O, Qian X. Salivary and serum inflammatory mediators among pre-conception women with periodontal disease. BMC oral health. 2016;16:131-37. https://doi.org/10.1186/s12903-016-0306-9

33. Choudhary A, Pati S, Patro R, Deorari A, Dar L. Comparison of conventional, immunological and molecular techniques for the diagnosis of symptomatic congenital human cytomegalovirus infection in neonates and infants. Ind J Med Microb. 2015;33:15-19

https://doi.org/10.4103/0255-0857.150874

34. Korsrud F, Brandtzaeg P. Quantitative immunohistochemistry of immunoglobulin-and J-chain-producing cells in human parotid and submandibular salivary glands. Immunolog. 1980;39:129-40

35. Podzimek S, Vondrackova L, Duskova J, Janatova T, Broukal Z. Salivary markers for periodontal and general diseases. Disease markers. 2016. Volume 2016, 1-8 Article ID 9179632

https://doi.org/10.1155/2016/9179632 
36. Wang A, Wang CP, Tu M, Wong DT. Oral biofluid biomarker research: Current status and emerging frontiers. Diagnostics. 2016;6:4560.

https://doi.org/10.3390/diagnostics6040045

37. Gómez-Rial J, Curras-Tuala M, Talavero-González C, RodríguezTenreiro C, Vilanova-Trillo L, Gómez-Carballa A, et al. Salivary epidermal growth factor correlates with hospitalization length in rotavirus infection. BMC infecti dis. 2017;17:370-74.

https://doi.org/10.1186/s12879-017-2463-0

38. Patel N, Belcher J, Thorpe G, Forsyth NR, Spiteri MA. Measurement of C-reactive protein, procalcitonin and neutrophil elastase in saliva of COPD patients and healthy controls: correlation to self-reported wellbeing parameters. Resp res. 2015;16:62-77.

https://doi.org/10.1186/s12931-015-0219-1

39. Sikirzhytski V, Virkler K, Lednev IK. Discriminant analysis of Raman spectra for body fluid identification for forensic purposes. Sensors. 2010;10:2869-84.

https://doi.org/10.3390/s100402869

40. Romano-Keeler J, Wynn JL, Maron JL. Great expectorations: the potential of salivary 'omic'approaches in neonatal intensive care. $\mathrm{J}$ Perinatolog. 2014;34:169-73.

https://doi.org/10.1038/jp.2013.170
41. Hassaneen M, Maron JL. Salivary Diagnostics in Pediatrics: Applicability, Translatability, and Limitations. Front Public Health. 2017;5-12

https://doi.org/10.3389/fpubh.2017.00083

42. Iyengar A, Paulus JK, Gerlanc DJ, Maron JL. Detection and potential utility of $\mathrm{C}$-reactive protein in saliva of neonates. Front Pediatrics. 2014;2;1-8.

https://doi.org/10.3389/fped.2014.00131

43. Scheidweiler KB, Spargo EAK, Kelly TL, Cone EJ, Barnes AJ, Huestis MA. Pharmacokinetics of cocaine and metabolites in human oral fluid and correlation with plasma concentrations following controlled administration. Therapeutic Drug Monit. 2010;32: 628-37

https://doi.org/10.1097/FTD.0b013e3181f2b729

44. Nunes S, Alessandro L, Mussavira S, Sukumaran Bindhu O. Clinical and diagnostic utility of saliva as a non-invasive diagnostic fluid: a systematic review. Biochemia Medica. 2015;25:177-92. https://doi.org/10.11613/BM.2015.018 